\title{
REHABILITATION OF HOUSING: FEDERAL PROGRAMS AND PRIVATE ENTERPRISE
}

\author{
Bernard E. Loshbough*
}

\section{INTRODUCTTON}

A basic fact of life for millions of people, particularly for those trapped in urban ghettos, is the need for adequate housing at a price they can afford to pay. The attack on the problem, until recent years, has centered on the tearing down of large areas of obsolescent, deteriorated housing, with the consequent dislocation of large numbers of people, which in turn has led to overcrowding and accelerated decay elsewhere.

More recently, industry and government people concerned with housing have been suggesting, and in some cases probing, another approach to the problem. This is to develop techniques for large-scale rehabilitation of basically sound but aging existing structures. The best estimates indicate that there are at least 5,000,000 substandard houses in the blighted areas of U.S. cities that are capable of rehabilitation. ${ }^{1}$

Obviously, from the public point of view, a massive effort is needed to transform this potential into reality within a reasonably short period of time. This calls for teamwork between the public and private sectors.

ACTION-Housing ${ }^{2}$ has formulated and is presenting to industry and government a thoroughly researched proposal directed at achieving a major breakthrough in the mass rehabilitation of housing. This new concept is based, in part, on this private, nonprofit civic organization's experience in renovating a group of twenty-two singlefamily, two-story attached, sixty-year-old houses in an aging Pittsburgh neighborhood. It has been prepared after a series of consultation conferences with industry's foremost administrators and research heads, and government leaders in housing.

The proposal, which will be explained in detail later in this article, calls for private enterprise to take the initiative in forming a new, broadly-based corporation which, in cooperation with government, would bring about housing modernization on a sizable scale, with particular attention to the needs of families of low and moderate income.

Others have expressed themselves as thinking along similar, if not precisely the same, lines. They include the President of the United States, several U.S. Senators of both parties, and chief executive officers of some of the nation's largest corporations and financial institutions. In April 1967 , Senator Charles H. Percy, addressing the thirty-sixth annual meeting of the National Housing Conference, observed: ${ }^{8}$

* Executive Director, ACTION-Housing, Inc.

${ }^{1}$ E.g., Finding a Profit in Slum Strets, Bus. WeEx, Feb. 4, 1967, at 52.

Allegheny Council to Improve Our Neighborhoods, Pittsburgh, Pennsylvania.

${ }^{3}$ Address by Senator Percy before the National Housing Conference, Washington, D.C., April ro, 1967. 
All the programs which encourage home ownership-whether it be a singlefamily home, row house, a share in a housing cooperative, or an apartment in one of the newer condominiums-are aimed at those families of middle or upper income. Those who may well need home ownership and profit from it most have been left out.

I am convinced that if home ownership, in its various forms, can be made a realistic possibility to the poor but aspiring family, they will surmount that motivation barrier and strive to achieve the economic security that can make ownership a reality for them.

The Senator, who is a member of the Senate's Banking and Currency Committee, urged the creation of a federally-sponsored National Home Ownership Foundation, to give technical assistance and make loans to local organizations conducting programs to help lower income families own their own homes or apartments. "Its purpose would be to mobilize the enormous resources of the non-government sector behind a national effort to expand home ownership opportunities for all Americans," he said.

While the Senator's program has areas of similarity, it differs from ACTIONHousing's private enterprise proposal, which concentrates on rehabilitation and would encompass rental as well as sales housing for families of low and moderate income. Senator Percy also proposed a program for increasing the supply of qualified housing specialists, which is one of the recommendations of the ACTION-Housing proposal, and establishing a fund to provide "seed money" to local nonprofit housing sponsors, which ACTION-Housing has performed on a smaller scale at the local level with its private enterprise Development Fund since I959.

It is evident that today both private enterprise and government, at the federal, state, and local levels, have become increasingly aware of the potential of a program of mass housing rehabilitation to answer the housing needs of urban families of moderate income, thus leading to the revitalizing of the declining neighborhoods of our cities.

Before expanding on ACTION-Housing's proposal to bring this about, it is important to the purpose of this article to recount the federal role in housing rehabilitation in the past.

The Federal Role in Housing Rehabilitation

\section{A. Background}

The depression inspired early federal ventures into residential rehabilitation. In 1933, the Home Owners' Loan Corporation (HOLC) was authorized to make loans to save the homes of families whose mortgages had been foreclosed as a result of the depression. ${ }^{5}$ An offshoot of this program resulted when the HOLC began making

\footnotetext{
'Id.

${ }^{5}$ Home Owners' Loan Act of 1933, ch. 64,48 Stat. I28.
} 
loans for the modernization and improvement of residential properties. ${ }^{8}$ And in 1934, title I of the National Housing Act authorized the Federal Housing Administration (FHA) to insure loans made by private lending institutions for the purpose of financing alterations, repairs, and improvements upon real property.

The importance of these two programs (HOLC and FHA) lies in the recognition of residential rehabilitation as a concept, rather than in the method in which it was handled. The aid was not confined specifically to older cities, urban areas, declining neighborhoods, and so on, but instead the loans went to property owners regardless of area. The primary criterion was financial distress of the borrower rather than the condition of the structure in which he lived. There was no plan or scheme to fit the rehabilitation effort into a broader concept of community planning.

A series of reports and studies published between 1940 and $195^{\circ}$ indicated the necessity for approaching housing rehabilitation on a neighborhood basis, with reference to the framework of the whole community. This approach was adopted in the Housing Act of $1949,{ }^{8}$ the principal law authorizing federal assistance to slum clearance and urban renewal. Under this act a series of federal financial aids to encourage rehabilitation and conservation of existing residential properties in deteriorating urban neighborhoods were sponsored. However, it was not until 1954 that these tools were organized into a comprehensive effort.

A brief summary of the housing acts of 1954 through 1965 reveals an evolution in federal efforts to provide meaningful legislation to assist revitalization of the urban housing supply.

\section{B. The Housing Act of $1954^{9}$}

In 1953, President Eisenhower appointed a committee to undertake a re-evaluation of the federal government's housing policies and programs. Largely through the efforts of James Rouse, a Baltimore mortgage banker, the committee recommended that the federal government (I) provide assistance to help communities attack the slum problem and urban decay, (2) provide federal loans and grants to communities for such purposes, and (3) extend the long-term FHA mortgage insurance into older communities to facilitate liberal financing to build and rehabilitate dwelling units for sale and rent. ${ }^{10}$

These recommendations were enacted into law in the Housing Act of 1954. The Act broadened the provisions of title I to authorize federal assistance for prevention

\footnotetext{
- See genetally Residential Refabilitation (M. C. McFarland \& W. K. Vivrett eds. I966).

${ }^{7}$ Ch. 847, \$2, 48 Stat. I246 (I934), as amended, I2 U.S.C. \$ I703 (I964, Supp. II, I965-66).

${ }^{8} \mathrm{Ch} .338,63$ Stat. $4^{\mathrm{r}} 3$ (codified in scattered sections of 12,42 U.S.C.).

${ }^{\circ} \mathrm{Ch} .649,68$ Stat. 590 (codified in scattered sections of I2, I8, 20, 3I, 40, 42 U.S.C.).

${ }^{10}$ See The President's Advisory Committee on Government Housing Policies and Programs, Recommendations on Government Housing Policies and Procrams (Report to the President of the United States, I953).
} 
of the spread of slums and urban blight through the rehabilitation and conservation of blighted and deteriorated areas.

\section{The Housing Act of $195^{6^{11}}$}

The Housing Act of $x_{95} 6$ further liberalized title I of the Housing Act of 1949 . It included, among other changes, a provision for the allocation of federal advances for the preparation of General Neighborhood Renewal Plans (GNRP). The GNRP was simply the designation of larger urban areas into combination urban renewal, rehabilitation, and conservation plans, but it was a significant step away from the total clearance approach. The first signs of neighborhood rehabilitation efforts began to work as federal policy. The campaign to encourage private rehabilitation of structures as part of a total neighborhood approach became an integral part of every urban renewal effort under the General Neighborhood Renewal Plan.

D. The Housing Act of $1959^{12}$

An expansion of the General Neighborhood Renewal Plan idea into a total community approach was an important aspect of the Housing Act of 1959 . New provisions for federal grants to Community Renewal Programs were liberalized under title I. Under this title, grants for the preparation or completion of Community Renewal Plans (CRPs) were authorized. The CRPs generally included, but were not limited to (I) identification of slum areas or blighted, deteriorated or deteriorating areas in the community, and (2) the measurement of the nature and degree of blight and blighting factors within such areas.

The desirability of a closely-integrated community renewal effort with comprehensive planning was recognized as an integral part of the 1959 Housing Act, for it made an attempt to combine good planning practice with common sense.

\section{E. The Housing Act of $196 \mathrm{I}^{13}$}

In I96I the need for a continued effort to maintain and improve the existing supply of urban housing was as great as, if not greater than, it was at the time of the passage of the Housing Act of 1954. In Ig6r, President Kennedy reaffirmed federal policy with regard to rehabilitation and conservation, and Congress passed the Housing Act of Ig6r. Once again title I of the Act was amended to include, among other provisions, authorization for local urban renewal agencies to carry out rehabilitation demonstrations in urban renewal areas.

This addition to title I was an important step in the process. For years the question of feasibility had been ignored. That is, was it feasible to rehabilitate and conserve older residential structures in certain urban areas? Improvement of the physical environment alone obviously was not enough in many run-down sections. Educa-

\footnotetext{
${ }^{11}$ Ch. 1029, 70 Stat. I091 (codified in scattered sections of I2, 40, 42 U.S.C.).

${ }^{12}$ Pub. L. No. 86-372, 73 Stat. 654 (codified in scattered sections of $12,40,42$ U.S.C.).

${ }^{13}$ Pub. L. No. 87-70, 75 Stat. 149 (codified in scattered sections of $12,15,40,42$ U.S.C.).
} 
tion, health, opportunities for employment, a sense of civic responsibility-all these and other human factors were involved. It makes no sense to rehabilitate houses when the people themselves are deprived, hopeless, and apathetic.

The Housing Act of Ig6I did not change the basic concept of residential rehabilitation, but it did add further legislative tools designed to make the program more effective. These were (I) liberalizing of FHA programs which were to be used to finance rehabilitation, (2) authorizing FHA to insure below-market interest rate loans used for rehabilitation carried out by nonprofit, limited dividend, or cooperative organizations, (3) insuring supplementary rehabilitation loans under section $220(\mathrm{~h})^{\mathbf{1 4}}$ based on any type of security acceptable to the FHA Commissioner, including second mortgage, and (4) calculating loan amounts for rehabilitation based on the value of existing property plus the cost of repairs.

\section{F. The Housing Act of $1964^{15}$}

The passage of the Housing Act of $x 964$ was a reaffirmation of national policy with another attempt to strengthen the Act of ig6r. Implementation of the legislative tools was still the critical question. However, some redefinition was added to increase the use of federal financial aid for home improvement loans in urban renewal and code enforcement areas. Thus the presumed purpose of section $220(\mathrm{~h})^{10}$ was to aid in the elimination of slums and blighted conditions and the prevention of the deterioration of residential properties by supplementing the insurance of mortgages.

To be eligible for insurance under section $220(\mathrm{~h})$ of this housing act, the mortgaged property had to be located in the area of a slum clearance and urban redevelopment project covered by the Housing Act of $\mathrm{r} 949$ and subsequent amendments. The improvements in section $220(\mathrm{~h})$ provided for further assistance in the conservation, improvement, repair, and rehabilitation of property located in the area of an urban renewal project, or in an area in which a program of concentrated code enforcement activities was being carried out. This expansion of powers also has permitted the authorization of loans and terms under a broader commitment basis, including advances during the construction or improvement period made by institutions on and after the enactment of the Housing Act of rg6r.

\section{G. The Housing and Urban Development Act of $1965^{17}$}

Until the Housing and Urban Development Act of 1965 , the majority of moderate income housing attempted to be built, rehabilitated, or conserved with the help of federal assistance in deteriorating urban areas was accomplished under sections 220 and 221 of the National Housing Act as amended through $1964{ }^{18}$ The Act of 1965

\footnotetext{
14 Pub. L. No. 87-70, § I02(a), 75 Stat. 154 , as amended, I2 U.S.C. $\$ 1715 k$ (h) (I964, Supp. II, I965-66).

${ }_{15}$ Pub. L. No. 88-560, 78 Stat. 769 (codified in scattered sections of $12,15,20,38,40,42$ U.S.C.).

${ }^{10}$ 12 U.S.C. \$ $1715 \mathrm{k}(\mathrm{h})$ (1964), as amended, (Supp. II, 1965-66).

${ }_{17}^{17}$ Pub. L. No. 89-II7, 79 Stat. 45I (codified in scattered sections of $12,15,20,38,40,42,49$ U.S.C.).

${ }^{18}$ I2 U.S.C. $\$ \$$ I715k, I7I5l (I964), as amended, (Supp. II, 1965-66).
} 
made significant strides toward providing housing for low and moderate income families.

The Act continued the moderate income housing provisions of the I96r Act and reduced the below-market interest rate to three per cent to assure lower rents. In addition, it provided a series of special provisions for disadvantaged persons which included:

(I) Authorization of the newly established Federal Department of Housing and Urban Development (HUD) to undertake a program of rent supplements to serve people who are in need of housing and are in the lower income range-eligible to receive public housing.

(2) Extension of the FHA section 22I programs.

(3) Section II5 rehabilitation grants to homeowners in urban renewal areas, enabling low-income homeowners whose dwellings are required by an urban renewal plan to be rehabilitated to improve their homes, and to remain in them, rather than be compelled to leave. These grants may go up to $\$ I_{3} 500$ for families whose incomes do not exceed $\$ 3,000$ yearly, or a lower amount, based on the need of homeowners with higher than $\$ 3,000$ per year income. $^{10}$

(4) Section $3^{\text {I2 }}$ rehabilitation loans for owners of properties in title I urban renewal projects or section II7 code enforcement areas. More restrictive in nature, these loans are not to exceed $\$ 10,000$ or an additional $\$ 4,500$ in high cost areas. These loans are limited to rehabilitation, and the cost may not exceed the cost of rehabilitation added to the amount of the existing debt secured by the property. The sum of the section $3^{\text {I2 }}$ loan and any remaining debt may not be more than $\$ 30,000$ for a single-family residence, $\$ 32,500$ for a two- or three-family residence, and $\$ 37,500$ for a four-family residence. ${ }^{20}$

The section $3^{\text {I2 }}$ loans are liberal with regard to financing. Whenever the principal and interest payments for a $3^{12}$ loan and the mortgage payments (principal and interest) exceed twenty per cent of the applicant's total income, the applicant is eligible for refinancing.

The principal purpose of the amendments to the section 220 terms was to remove obstacles which restricted the use of FHA section 220 programs as they apply to non-occupant owners, particularly in urban renewal areas.

Non-occupant mortgagors of one- to eleven-unit residential rental housing would be entitled to a larger loan amount more consistent with those on larger multifamily structures. The amendments would also include refinancing to permit existing indebtedness for improvement of the property to be included in the computation

\footnotetext{
10 U.S. Urban Renewal administration, Housing and Home Finance Agency, Local Public Agency Letter No. 342 (Aug. I965).

${ }^{\circ 0}$ U.S. Urban Renewal Administration, Housing and Home Finance Agency, Local Public Agency Letrer Nos. 3707, 335, 340, 34 I (Sept., June, Aug. I965).
} 
of the amount of a mortgage, whether or not the indebtedness secured by the property was included in the insured mortgage.

Under the 1965 Act, with funding in 1966 , an experimental program in home ownership has been launched under section $22 \mathrm{I}(\mathrm{h}){ }^{21}$ It provides for the sale of new or rehabilitated houses to persons of low and moderate income at below-market interest rate mortgages (three per cent), if the buyer meets all the family composition and annual income requirements necessary for section $22 \mathrm{r}(\mathrm{d})(3)^{22}$ rental families. However, the funds allocated for section $22 \mathrm{I}(\mathrm{h})$ are minimal-not exceeding $\$ 20$ million.

Thus far we have seen the "premise" of federal legislation in the recognition of the need for financial tools to assist urban areas in the rehabilitation of residential structures. Also traced has been the steady progression of these tools from their earlier development to the present comprehensive laws which are attempting to deal with the problems of (I) conserving the nation's urban housing supply, (2) providing housing for families of low and middle income, and (3) erasing the present signs and causes of blight in urban areas.

\section{II}

\section{Problems in the Use of Federal Programs}

Federal recognition of the problems of residential rehabilitation and conservation has been progressive, but not all that has been proposed has been achieved. Many of the difficulties in the use of the federal tools can be attributed to the complexities of dealing with civic and private institutions, people, and ideas. These major drawbacks require explanation and amplification.

A major difficulty arises in the area of code standards and enforcement. One of the most crucial steps in the systematic achieving of neighborhood rehabilitation is the establishment of rehabilitation standards that are in accordance with present or proposed re-use plans. This critical aspect, which bears directly on the feasibility of using federal financing, is a program in and of itself. Trained personnel are needed who are familiar with codes, construction, and financing, for value judgments have to be made both for the property owner and the community as a whole. What will it take in terms of rehabilitation dollars to balance the old with the proposed new; will repair be more predominant than replacement on an item-by-item basis; and what best combination of detailed standards will provide decent, sanitary, and safe housing? All of these factors in the final analysis will determine whether or not the use of the federal financial aid is feasible.

Just as the establishment of code standards is a crucial step, so is the interpretation and enforcement of the code standards. The interpretation by local FHA insuring

\footnotetext{
${ }^{21}$ 12 U.S.C. $\$ x_{715 l(h)}$ (Supp. II, 1965-66).

${ }^{22} 12$ U.S.C. \$ I7I5l(d)(3) (Supp. II, x965-66).
} 
offices of urban renewal and FHA code requirements has presented, and still presents, a major stumbling block in the effective rehabilitation and conservation of existing residential structures through the use of federal resources. All too often the local, urban renewal and federal standards are at odds. What might be acceptable property standards under an urban renewal plan might be unacceptable to the FHA-insuring office for loan purposes, and vice versa.

To correct this problem the Federal Housing Administration has recently established "minimum property standards" for urban renewal rehabilitation. ${ }^{23}$ These standards now provide a national basis for standards used in rehabilitation projects located in urban renewal areas for residential structures containing one through eleven units. The determination on the part of the government to add flexibility where it previously was non-existent can be seen in the development of these standards. On the one hand, there is the establishment of a minimum level below which FHA insurance will not be provided; on the other hand, the standards are interpreted as suggestions for which no mandatory level is established. Thus, while guaranteeing items pertaining to safety and sanitation, flexibility is built in to help establish feasibility.

Obviously, the effectiveness of a housing code depends upon its contents and its enforcement. Adequate standards must be implemented with firm and vigorous enforcement. In many cities the enforcement of housing codes has been replete with difficulties-lack of sufficient funds and staff, the dispersion of inspection responsibilities among several bureaus or departments, the handling of inspections on a complaint rather than area basis, the ineffectiveness of court action, and the lack of adequate relocation resources to back up vigorous enforcement.

The importance of housing codes is stressed in an integral part of the Housing Act of $\mathrm{r} 949$ as amended. The Act provides that no contract shall be entered into for any capital grant or loans for urban renewal, nor any mortgage insured under sections 220 or 221 of the National Housing Act, and no annual contributions or capital grant contracts for public housing shall be entered into, unless there is presented to the Administrator of the FHA by the locality a workable program of the community for utilizing private and public resources to eliminate present slums and prevent their spread in the future. ${ }^{24}$

Another hindrance to the effective use of federal financial aids is the procedure required by local lending institutions and FHA to process an application for use of funds to promote rehabilitation. This tedious and complicated procedure is confusing to the majority of homeowners and developers. The process is not a simplified one and requires the time of specialists. Most homeowners are not familiar with the procedure and lack the expertise to accomplish it. Most lending institutions would prefer not to get involved because of time-money factors. Larger developers hire

\footnotetext{
98 U.S. Federaz Hodsing Administration, Dep't of Hodsing and Urban Development, Minimum Property Standards for URban Renewal Rehabilitation (I966).

at $\S \operatorname{IOI}(c), 42$ U.S.C. $\S$ I 45 I (c) (Supp. II, I965-66).
} 
specialists but pass the cost on to the subsequent user, thus raising costs and obviating the use of the rehabilitated units for the low- and middle-income users.

III

\section{The ACTION-Housing Proposal}

In spite of these problems, many of the best brains of industry and government have nevertheless come to the conclusion that the most feasible way to eradicate blight in our cities is to rehabilitate, on a large scale, existing deteriorating but structurally sound housing, particularly for families of low and moderate income. This calls for teamwork between the public and private sectors. The tools are available, as provided by the federal legislation. There is a profit incentive as well as a civic motive for private industry. The need is for a catalyst to join all forces.

Pittsburgh's ACTION-Housing, Inc., is advancing such a proposal to top industry administrators and research heads and government representatives concerned with housing. The proposal recommends that private enterprise organize and operate a new profit-making development corporation to conduct full-scale modernization of deteriorating urban housing, initially in the Pittsburgh metropolitan area, in cooperation with the local, state, and federal agencies. It suggests very close interaction between private enterprise and the public sectors in carrying out the program.

Here Pittsburgh has an opportunity to lead the nation in providing a creative and effective solution to a troublesome public problem. The most likely source for this kind of effort is the private sector, particularly our large corporate entities with their tremendous resources in human talent, technological know-how, financial strength, and problem-solving capabilities.

The motivation for involvement in this effort may vary from one company to another. It may be enlightened self-interest for those that have a direct stake in the general community environment, or the acceptance of the challenge of civic responsibility, or direct commercial interest in terms of enlarging the market for products and services in the housing field. These are opportunities for business to demonstrate what it can achieve through the appropriate application of its capabilities in an area of broad public concern.

The profit motivation for those companies whose capabilities mesh with the commercial opportunities inherent in this field should not be de-emphasized. To be perfectly pragmatic, in the long run this motivation offers the most potent stimulant for action on a massive scale. After all, our profit-motivated system has proven itself to be the most prolific provider for human needs and wants yet known to man.

What is called for, then, is a mechanism which can successfully blend all of these motivations into a single concerted attack on the problem of mass housing rehabilitation and at the same time provide a laboratory for experimentation in this field through which individual companies can gain experience and confidence, and ulti- 
mately, hopefully, proliferate this effort on an ever-expanding scale. This is really what the ACTION-Housing proposal is all about.

\section{A. Summary}

This proposal recommends the formation of a new corporation, capitalized at $\$ 3$ million to $\$ 4$ million, to engage in the rehabilitation of structurally sound but deteriorating housing in the Pittsburgh metropolitan area, on a profit-motivated basis, in cooperation with the local, state, and federal agencies. Participating companies would commit to purchase common stocks or debentures. Policy would be established by a board of their selection. Professional staff and management personnel would be provided by the newly-created company. The Pittsburgh demonstration by the proposed Allegheny Housing Rehabilitation Corporation (AHRCO) would, when experience has proven it successful, constitute a prototype which could be repeated in many cities throughout the nation.

\section{B. Details of the Proposal}

Allegheny County contains 503,000 dwelling units, of which it is estimated approximately 90,000 need and are susceptible of rehabilitation. Of these, 40,000 are in the City of Pittsburgh. A total of approximately $x 7,000$ dwelling units in the City and County are beyond restoration and should be demolished.

Total clearance and redevelopment of the area in which the 90,000 units are located is monetarily and otherwise not feasible. Public housing in Pittsburgh has averaged less than 325 units per year in the last thirty years, although the rate has increased in the last few years to about 430. At this rate, including consideration of private building and rehabilitation, Allegheny County's inventory of substandard housing will increase.

As a demonstration, ACTION-Housing, Inc., undertook in 1966 the rehabilitation of twenty-two row houses on Cora Street in the Homewood-Brushton area of Pittsburgh. ACTION-Housing acquired the properties for about $\$ 4,000$ each and expended approximately $\$ 6,000$ additional per unit to provide good housing for twentytwo families in that neighborhood at a rental only slightly higher than previous payments.

Construction work was performed by a private contractor; interim financing was provided under a participation agreement by the Mellon National Bank and Trust Company and the Development Fund of ACTION-Housing, Inc. The permanent mortgage financing was obtained from the federal government under its belowmarket interest rate program (section $22 \mathrm{I}$ (d)(3) of the National Housing Act), which provides three per cent funds and up to a forty year mortgage term for roo per cent of the total costs where the mortgagor is a nonprofit corporation like ACTION-Housing, Inc. Limited dividend corporations could secure a mortgage for ninety per cent of the total costs. 
The Cora Street rehabilitation has had a distinct advantage in being located in a neighborhood which has a strongly structured Citizens Renewal Council, a pioneer urban extension group which ACTION-Housing helped to organize and has given professional guidance to for seven years. The Council has leadership and participation by neighborhood people, as well as backing by the major industries and merchants of the neighborhood. When the Cora Street project was first publicly announced, the then president of the Council said: "The modernization of whole sections of basically sound housing will provide the visible evidence of change that should inspire us all."25

Although Cora Street has demonstrated obstacles and need for changes in procedures, the following conclusions were reached:

(I) Such work is feasible and provides a good end-result for tenants of low and moderate income without major dislocation. Tenants are happy with the housing.

(2) A reasonable profit is available to developers, subject to normal business risks, and to persons providing services (e.g., architect, contractor, lender, attorney, realtor).

(3) This form of private enterprise development provides advantages in cost, markets, and time over new construction and other current housing programs.

(4) Major expansion of this concept requires substantial capital and private enterprise production techniques and purchasing power.

(5) Such an undertaking provides an immense sociological benefit to older neighborhoods in decaying urban communities-an urgent necessity in halting further deterioration and social strife.

Major capital, private enterprise methods, and the affirmative cooperation of federal, state, and local governments are essential to provide quantity rehabilitation for impact upon Allegheny County communities.

Secretary Robert C. Weaver has signed an agreement between ACTION-Housing and the Department of Housing and Urban Development concerning the proposed pilot rehabilitation project in Pittsburgh. For its participation in the plan, the federal government offers financial resources, technical advice, streamlined Federal Housing Administration processing, and an array of programs through which most families of low and moderate income can qualify for the housing.

Philip N. Brownstein, Assistant Secretary and Federal Housing Administration Commissioner, sees the ACTION-Housing proposal as using five major program concepts, and possibly a sixth. They are, in his words $:^{28}$

\footnotetext{
${ }^{26}$ News Release, ACTION-Housing, Inc., Aug. I, 1966.

${ }^{20}$ Address by Mr. Brownstein, typed copy issued by the U.S. Federal Housing Administration, Dep't of Housing and Urban Development, June 20, 1967.
} 
(I) Through Federal support of the Urban Renewal Program, we can have price write-downs to keep some rents within the means of the families to be served. This is for properties in urban renewal areas.

(2) and (3) For low-income families, there is a choice between the public housing lease approach or the much maligned and little understood rent supplement program. For the first, the landlord would be the public housing authority, and the second would be privately owned by a nonprofit organization or limited-dividend corporation with the government making a contribution toward the rent in each case.

(4) The proposition also calls for the use of a program to bring home ownership to low-income families through the use of below market interest rate funds.

(5) Another possibility is the turnkey approach to public housing, in which a private builder sells the finished product to the public housing authority.

(6) Still another program uses the below-market interest rate approach to provide rental units for families of modest means.

In a June 7,1967 , letter of transmittal concerning the agreement with ACTIONHousing, Secretary Weaver emphasized the importance of involving minority group members in the construction. He offered a three-point program of goals to be developed with the contractors and the unions, at the local level:27

$x$. Where qualified minority group journeymen and apprentices are available in the Pittsburgh area and individual unions are not now "open," those unions should guarantee that a maximum number of such persons will be employed in the rehabilitation work.

2. Where minority group members lack the needed skills, a training program should be developed-jointly by management and labor-to provide them with the skills needed for employment in the construction industry.

3. The creation of a special category of workmen-known perhaps as "rehabilitation specialists"-should be explored with the unions and the Department of Labor. These specialists would cut across jurisdictional lines and would facilitate the utilization of minority group workers in rehabilitation projects.

Secretary Weaver made the point that involvement of minority workmen will serve many purposes which transcend compliance with the law. He feels that such involvement of minority workmen will enhance the initial reception and ultimate acceptance of the program by the indigenous community and "a reduction of intergroup tension is bound to result in Pittsburgh if a forthright attempt is made to end discrimination in the building trades."28

The agreement with the Department of Housing and Urban Development was announced at a dinner for ${ }^{6} 67$ outstanding leaders of the Pittsburgh area, and elsewhere, to launch the Allegheny Housing Rehabilitation Corporation. At the dinner, held June 20, 1967, Anthony J. Furlan, President of the Pittsburgh Building Trades Council, spoke briefly but to the point in pledging the support of unions. He said:

\footnotetext{
${ }^{27}$ Agreement between ACTION-Housing, Inc. and the Department of Housing and Urban Development, June 7,1967 .

${ }^{28} I d$.
} 
"We are going to hire members of minority groups to do construction work and cross jurisdictional lines with composite work crews." ${ }^{\text {"20 }}$ This statement was applauded as a most significant breakthrough.

The City of Pittsburgh promised every effort to implement the development of the undertaking. There were meetings with the City Solicitor, the Director of Public Safety, the Executive Director of the Planning Department, the Superintendent of the Bureau of Building Inspection, the Mayor's Executive Secretary, and members of their staffs. Joseph M. Barr, Mayor of Pittsburgh, reported in writing: ${ }^{80}$

As a result of these discussions, there was agreement that the proposals for major rehabilitation of neighborhood housing for low and moderate income families warrant modifications of our building and zoning codes to effect the objectives of the rehabilitation program.

I am therefore planning to submit to City Council a series of recommendations amending these codes to facilitate large-scale rehabilitation of housing financed through special federal mortgage assistance for low and moderate income families.

These changes will include the redefining of work permitted under rehabilitation standards in the building code and modification of the zoning code to permit rehabilitation for non-conforming uses. I am convinced that effective housing rehabilitation is the key to making new federal programs like Model Cities succeed in Pittsburgh, without the large-scale clearance, dislocation of families, and neighborhood disruption associated with the normal urban renewal process.

The support for AHRCO of the U.S. Departments of Housing and Urban Development and Labor and the City of Pittsburgh having been cited, it is pertinent to record the response of one of the leading business executives of the nation-James F. Oates, Jr., Chairman of the Board of the Equitable Life Assurance Society. In a recent letter to Richard K. Mellon, Mr. Oates said: ${ }^{31}$

The Society is very much interested in the ACTION-Housing proposal for the creation of the Allegheny Housing Rehabilitation Corporation. We are prepared to consider becoming an active participant in this proposal.... We compliment you on the excellent approach you are taking to solve this most important challenge to our urban existence.

\section{AHRCO: Its Modus Operandi}

A preliminary survey by qualified appraisers has indicated that sufficient housing might be acquired in the open market to initiate a major rehabilitation program in the Pittsburgh area. Continuation of the program over an extended period will require close cooperation of the Urban Redevelopment Authority. As the program progresses, high annual rates of acquisition will force the market up, but the Urban Redevelopment Authority, by providing necessary "write-downs" where required, can

\footnotetext{
${ }^{20}$ Address by Mr. Furlan before the presentation dinner for the proposed Allegheny Housing Rehabilitation Corporation, Pittsburgh, Pa., June 20, 1967.

${ }^{80}$ Letter from Mayor Joseph M. Barr to ACTION-Housing, Inc., June 15, I967.

${ }^{31}$ Letter from James F. Oates, Jr., to Richard K. Mellon, June 7, 1967.
} 
control this cost factor. This cooperation would make it possible for AHRCO to rehabilitate old housing for families of low and moderate income at a monthly cost they could afford to pay.

The Allegheny Housing Rehabilitation Corporation would acquire housing units, arrange for interim financing, secure architectural services, and perform or contract for their rehabilitation. Completed units could be sold to eligible nonprofit corporations, limited dividend entities, cooperatives, or individuals, approved by FHA and eligible for the special assistance mortgage programs available under existing housing acts. An alternative approach is the sale of units to public housing agencies under the so-called turnkey program. AHRCO also would have the option of retaining units for long-range investment.

Inasmuch as no housing rehabilitation industry exists today, major development effort will be required of material suppliers, architects, contractors, and labor. New materials, methods of work, material application, construction systems, training programs for business and labor, and financing are indicated for long-term success of a major housing rehabilitation program.

\section{Recommendation}

It is recommended that the major Pittsburgh-based companies and others, to the extent that they are interested in housing rehabilitation, form an operating company (AHRCO) capitalized at $\$ 3$ million to $\$ 4$ million for the purpose of buying structurally sound but substandard housing principally in, but not limited to, Allegheny County, then rehabilitating and selling, or holding and renting it.

The level of financing suggested is believed to be sufficient to build up to and sustain a rate of $x, 000$ housing units annually, provided that housing units are turned over in about one year. Based on the assumptions shown in the exhibits attached as an appendix to this article, cash flow would be sufficient in the fifth year after formation to commence payment of dividends.

It is also recommended that a nonprofit research organization be formed to which AHRCO would subscribe ten per cent of its gross profits. The research company, with grants from foundations, governments, and AHRCO, would sponsor research on construction-methods and materials-application problems requiring solution.

Upon acceptance in principle of this proposal by a sufficient number of companies, ACTION-Housing will undertake to form a shareholder's committee to draw up the required agreements for formation and financing the proposed operating company (AHRCO). After formation of the company, ACTION-Housing, Inc. would be retained by it in a consulting capacity.

Final determination of staff, rate of growth, and volume of business, will be determined by the board of directors of the new company. A series of exhibits which illustrate how the company might be organized and operated is included in the appendix. 
The structure of the AHRCO proposal indicates that no financial losses would be incurred by the group of companies subscribing to the development corporation. We believe there would be a profit from the sale of houses. A huge rehabilitation market does exist, and there is an exciting opportunity and challenge to develop it on a profit-motivated basis. Profit is not the primary incentive, however, nor is the sale of products.

The major corporations whose interest has been kindled by the proposal see their real benefits as rebuilding and enhancement of the total environment of American cities, where most of them are located and where most of their employees live and work. An enlightened self-interest, if you will.

In the words of J. Stanley Purnell, ACTION-Housing's Chairman of the Board and President: ${ }^{32}$

Mass rehabilitation of existing housing for families of low and and moderate income has been caught in an economic stranglehold. It has been scattered, haphazard, and on too limited a scale to be significant.

Can it be that we, a nation of builders, have not learned the economics of rebuilding? Or how to develop and adapt space-age construction systems and technologies to housing rehabilitation?

This presents an opportunity for private enterprise to take the lead. It can in cooperation with government, using all the federal tools available, create a new profit-motivated industry. At the same time it would fulfill a well-documented social and physical need.

\section{E. Proposed Federal Legislation}

Two prominent U.S. Senators, one Democrat and one Republican, are presenting in the Senate major proposals for providing more and better low-cost housing, through a partnership between private enterprise and government. The AHRCO proposal has been designed to conduct large-scale housing rehabilitation for families of moderate income-between $\$ 4,000$ and $\$ 9,000$. It assumes that some form of federal subsidy is required to house very low income families.

New York's Senator Robert F. Kennedy has a plan, ${ }^{33}$ based partly on experience in a program initiated six months ago in the Bedford-Stuyvesant section of Brooklyn, to achieve two objectives through a combination of tax incentives, low-interest mortgages, and other devices. The first objective is low-cost housing for the poor, and the second is a substantial return on investment for private entrepreneurs who build such housing.

The Kennedy plan suggests the construction or rehabilitation of 300,000 to 400,000 low-cost housing units over the next seven years, and postulates the possibility of rents no greater than $\$ 100$ a month and some as low as $\$ 73$ a month in all of these

\footnotetext{
${ }^{33}$ ACtiON-Housing, Inc., Proposal for the Creation of the Alzegheny Housing Rehasilitation CoRPORATION 6 (1967).

${ }^{33}$ S. 2088, 90th Cong., Ist Sess. (1967); S. 2100, 90th Cong., Ist Sess. (1967).
} 
units. The assumption is that, following the yardstick of a twenty-five per cent expenditure of monthly income on rent, such rentals would be within the range of families with an annual income of between $\$ 3,500$ and $\$ 4,800$ annually.

Low, federally subsidized mortgages are called for by the Kennedy plan to keep rents down. The builder agreeing to construct low-cost units in a declining urban neighborhood would receive mortgage insurance of up to eighty per cent of the cost of the project, amortized over fifty years at a rate of two per cent annually.

The investor would have to contract to build or rehabilitate at least Ioo units whose rentals would be fixed by the federal government, and agree to meet basic standards of design and maintenance. He would accept a basic, direct return on his equity of only three per cent. However, there would be tax incentives, a primary one being an "investment credit." This would call for a scale of credits ranging from three per cent for the person who invests $\$ 200,000$ in a project-the "credit" being $\$ 6,000-$ to twenty-two per cent for the person or company who invests roo per cent, one who builds a project entirely with his own cash. The plan also calls for accelerated depreciation, as low as ten years for investors who put up the full cost of the project.

There is an overall promise of a net return for investors who build low-rent housing of between thirteen and fifteen per cent.

The Republican bill to provide home ownership for the poor, ${ }^{34}$ developed and sponsored by Senator Charles H. Percy of Illinois, has been outlined earlier in this article. Senator Percy attended the dinner meeting in Pittsburgh on June 20, x967, to launch the AHRCO proposal. It is worth noting that that meeting was co-hosted by the following seven executives of Pittsburgh-based corporations: L. B. Worthington, President, United States Steel Corporation; John D. Harper, President, Aluminum Company of America; D. C. Burnham, President, Westinghouse Electric Corporation; F. L. Byrom, President, Koppers Company, Inc.; R. F. Barker, President, PPG Industries; R. E. Seymour, President, Peoples Natural Gas Company; Philip A. Fleger, President, Duquesne Light Company. Richard K. Mellon, President of T. Mellon \& Sons, hosted a reception before the dinner. Top management of more than forty national corporations, FHA Commissioner Brownstein, and other government officials at federal, state, and local levels, were present. Support for the concept was advanced by Pennsylvania's Governor Raymond P. Shafer, Senators Joseph S. Clark and Hugh Scott, and others.

Senator Percy took back to Washington a documentary film relating the Cora Street experience, for presentation in the Senate auditorium. In the Congressional Record of June 23, I967, wherein the entire AHRCO proposal is published, ${ }^{35}$ Senator Percy related his reactions to the proposal, of which the following is an excerpt: ${ }^{.6}$

\footnotetext{
${ }^{34}$ S. 1592, 9oth Cong., Ist Sess. (1967).

${ }^{35}$ II3 CoNG. Rec. S88II (daily ed. June 23, I967).

${ }^{30} \mathrm{Id}$. at $\mathrm{S} 88 \mathrm{io}$.
} 
Nowhere ... do I know of such a comprehensive, well-conceived attack on slum housing and community problems, nor have I ever seen such a concerted effort by every sector of the community to build a better city. Again, the city that turned blight into the golden triangle is truly showing the way in this vital area.

There are those who scoff at such ventures. There are those who say that business and labor and Government can never reach a smooth, effective, working agreement to achieve such lofty goals. I invite those people to go to Pittsburgh, as I did, and see for themselves.

The problem of large-scale housing rehabilitation has existed and been defined and redefined for generations. Today the tools and knowledge are available to solve it, and it seems evident that the AHRCO proposal could bring about such rehabilitated housing for families of moderate income, and even families of low income if rent supplement money is available. Legislation such as that being introduced by Senators Percy and Kennedy, if enacted, apparently would help make it possible to provide both new and rehabilitated housing for more families of low income through a joint venture of private and public enterprise with private industry taking the leadership. 
APPENDIX

MODEL HOUSING REHABILITATION CORPORATION

exhibit

no. 1

\section{organization chart}

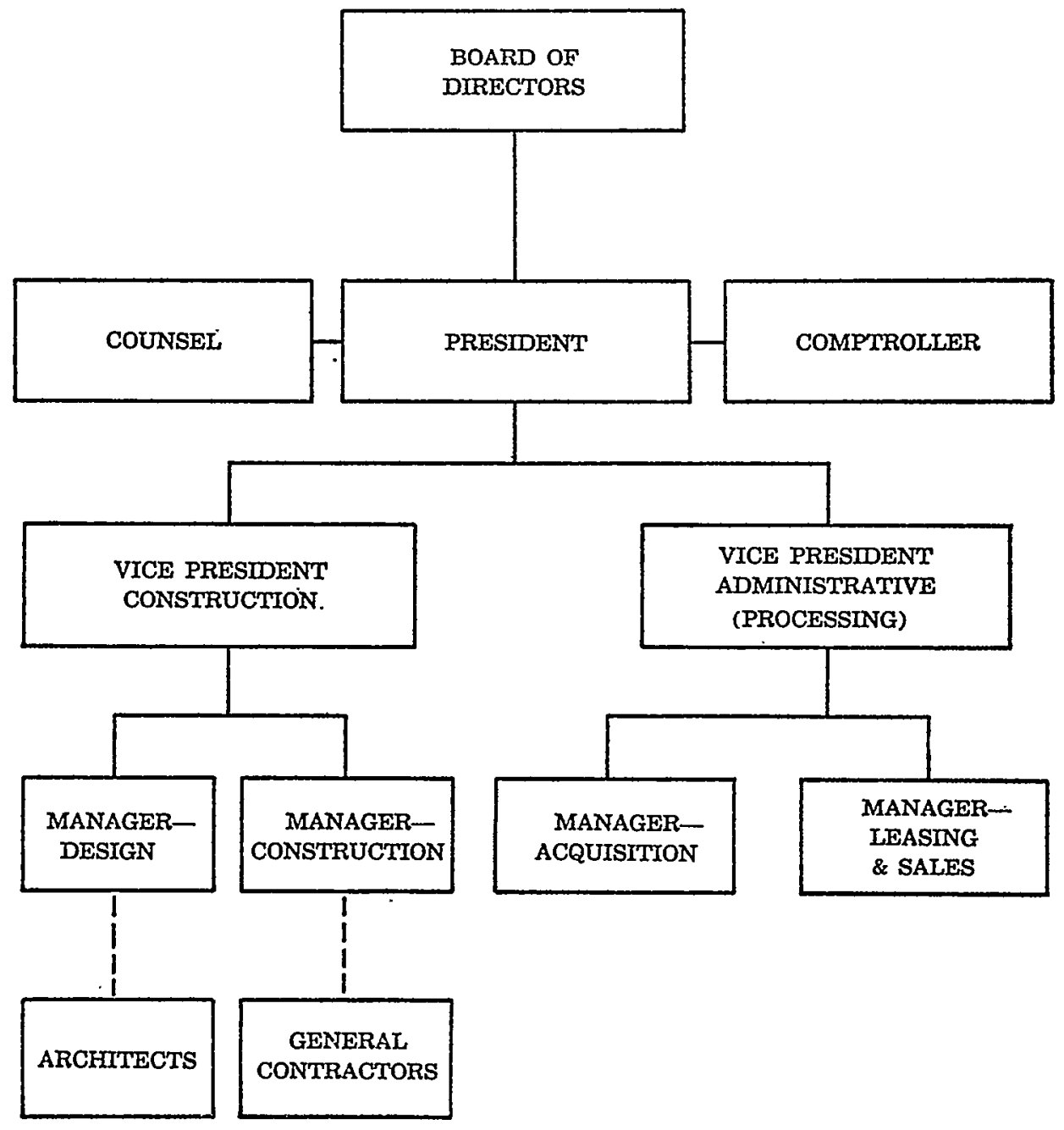


1. Personnel

A. President

B. Vice Presidents. 1 at $\$ 24,000$

C. Attorney 1 at 20,000

D. Comptroller

E. Managers

Construction.............................. 18,000

Design. ...................................... 15,000

Acquisition . . ................................ 14,000

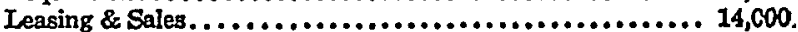

F. Clerical

Secretaries/Typists

$(6$ at $\$ 6,000) \ldots \ldots \ldots \ldots \ldots \ldots \ldots \ldots \ldots \ldots \ldots \ldots \ldots \ldots . \ldots, \ldots, 000$

Clerks

G. Engineers, Draftsmen, Job Superintendents,

Construction Analysts/Inspectors

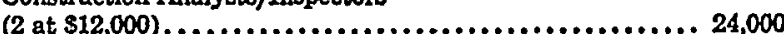

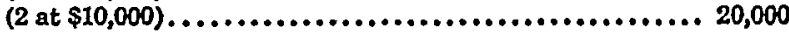
Draftsmen

$(4$ at $\$ 8,000) \ldots \ldots \ldots \ldots \ldots \ldots \ldots \ldots \ldots \ldots \ldots \ldots \ldots \ldots \ldots \ldots \ldots \ldots \ldots . \ldots, \ldots, \ldots, \ldots, \ldots \ldots$

Engineer..................................... 12,000

H: Fringes ( $15 \%$

\section{SUB-TOTAL}

TOTAL - EMPLOYMENT COSTS

$\$ 35,000$

44,000

18,000

18,000

61,000

72,000

88,000

$\$ 336,000$

50,000

$\$ 386,000$

II. Office Expenses

Rent.........................................\$18,000

Communications.................................. 6,000

Printing \& Supplies. ..... . . . .................... 8,000

Transportation \& Trips. ........................., 10,000

Furniture/Fixtures............................10,000

$\$ 62,000$

1II. Purchased Services

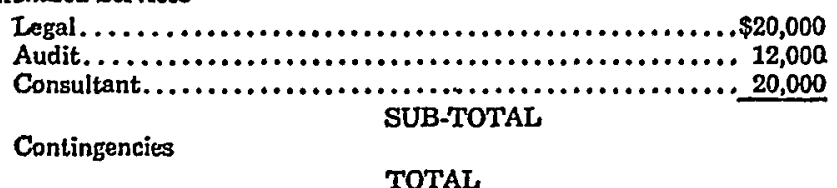

$\$ 62,000$

$\$ 490,000$

10,000

$\$ 500,000$ 


\section{exhibit \\ WORKING CAPITAL REQUIREMENTS-1,000 UNITS ANNUALIY no. 3}

Estimated Acquisition Costs

(@ $\$ 4,000$ each)

Less: Initial Mortgage Loan (60\%)

Cash Requirements for Acquisition

Rehabilitation Cost. ..........................\$ $6,000,000$

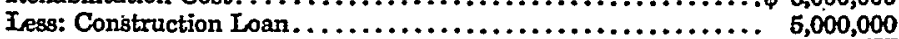

Balance:

Plus: General Overhead

$\$ 4,000,000$

$2,400,000$

$\overline{\$ 1,600,000}$

$1,000,000$

500,000

TOTAL

$\$ 3,100,000$

1. Acquisition Costs

2. Improvement Costs

$\$ 4,000$

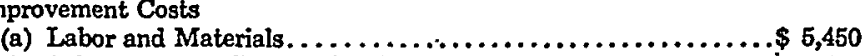

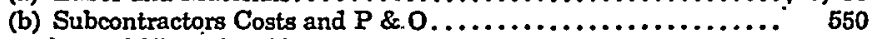

3. Carrying and Financing Charges

(a) Interest (12 mos. at $6 \% \times \$ 6,000$ avg.) .............. 180

(b) Taxes and Insurance. $\ldots \ldots \ldots \ldots \ldots \ldots \ldots \ldots \ldots \ldots \ldots \ldots, 150$

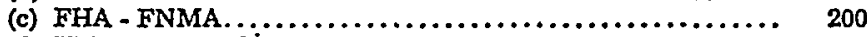

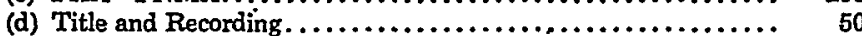

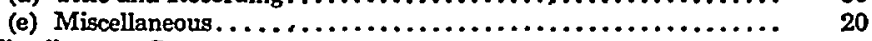

4. Miscellaneous Costs
(a) Contingencies (Construction) $\ldots \ldots \ldots \ldots \ldots \ldots \ldots \ldots \ldots \ldots \ldots, 300, \ldots \ldots \ldots \ldots \ldots \ldots \ldots \ldots \ldots \ldots$

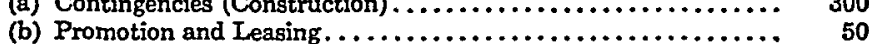

(c) Transfer Costs................................ 50

5. Estimated Sales Price

TOTAL COSTS

6,000

600

400

6. Less Total Costs

7. Gross Profit

8. Less:

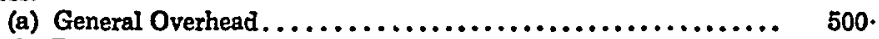

(b) Reserves. ............................................ 50

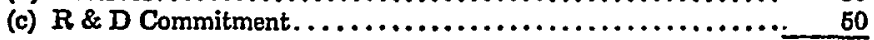


I. Construction

\section{Gross Profit/Overhead Allowance}

(10\% $\times$ Gross Costs) . ............

2. Estimated Net Profit (before taxes)

$\$ 1,100.00$

$600.00 *$

II. Ownership .

1. Annual Maximum Allowable Dividend

(6\% $\times 11.11 \% \times \$ 10,900$ mortgage). .

2. Potential Maximum Surplus Accumulation

(7\% vacancy factor @ $\$ 100$ mo. rent)

72.60

3. Estimated Amortization

(1.3\% x $\$ 10,900-1$ st year)

4. Replacement Reserves (estimated)

5. Depreciation (non-component) - Iot year

a. Straight-line

$(23 / 2 \% . \times 10,900)-\$ 272.50$

b. Double-declining - 545.00 .

6. Possible Tax Result (1st year)
a. Income (Items $\sharp 1,3,4$ )

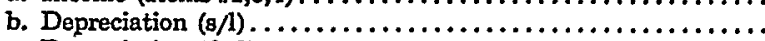
c. Depreciation (d/d)
d. $\operatorname{Tax} \operatorname{Tos}(\mathrm{s} / \mathrm{A})$ :
e. Tax Loss. (d/d)
f. Tax Free Cash Flow:

III. Sale After Ownership (1 year)

1. Recovery"-Profit/Overhead Allowance.

3. Reserves

-Subject to rate of annual production and initial costs (See Exhibit No. 8) "Plua: Cumulative Tax Benefits 
REIAATIONSHIP OF INCOME, RENT AND COSTS no. 6 (FHA 221 (d) (3) BMIR PROGRAM-PITTSBURGH-MARCH 1967)

\begin{tabular}{c}
$\begin{array}{c}\text { Persons } \\
\text { Per Family }\end{array}$ \\
\hline 2 \\
3 \\
4 \\
5 \\
6 \\
$7+$
\end{tabular}

\begin{tabular}{c}
$\begin{array}{c}\text { Unit Size } \\
\text { (Bedrooms) }\end{array}$ \\
\hline $1-2$ \\
2 \\
$2-3$ \\
3 \\
$3-4$ \\
4
\end{tabular}

\begin{tabular}{c}
$\begin{array}{c}\text { Maximum } \\
\text { Annual Income }\end{array}$ \\
\hline$\$ 5,950$ \\
7,000 \\
7,000 \\
8,050 \\
8,050 \\
9,100
\end{tabular}

\begin{tabular}{c}
$\begin{array}{c}\text { Maximum* } \\
\text { Monthly Rent }\end{array}$ \\
\hline$\$ 99.50$ \\
117.00 \\
117.00 \\
134.50 \\
134.50 \\
151.67
\end{tabular}

Probable

Maximum

*20\% of income

\section{exhibit} no. 7

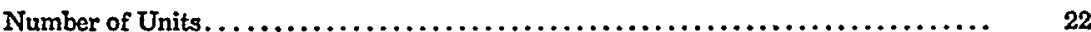

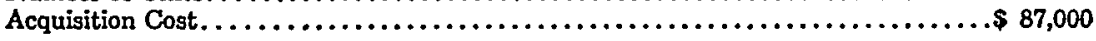

Improvement Costs:
Construction . . ..................... 117,900
Carrying Costs. . . . . .
Architect's Fees. . . . . . . . . . . .
Other Fees/Costs. . . . . . . . . 16,200

Total: All Costs. ................................\$229,300

Mortgage.................................... 228,000

Cash Equity . . . . . . . . . . . .

Time Elements:

Acquisition/Mortgage Processing -8 months

Construction -8 months

Ieasing (During Construction)

Ieasing Data and Status:

Pre-Acquisition Rents. . . . $\ldots \ldots \ldots \ldots \ldots \ldots \ldots$ 60-65

Plus Utilities. . . . . . . . . . . . . . . . . . . . . .

Post Improvement

Rents (average)

(Utilities, Decorating, and Repairs.

Management \& Reserves incl.)

Mortgage Terms:

Amount per unit - $\$ 10,200$

Term - 38 years, 7 months

Interest (During Construction) - 51/2\%

(After Completion) $-3 \%$ 


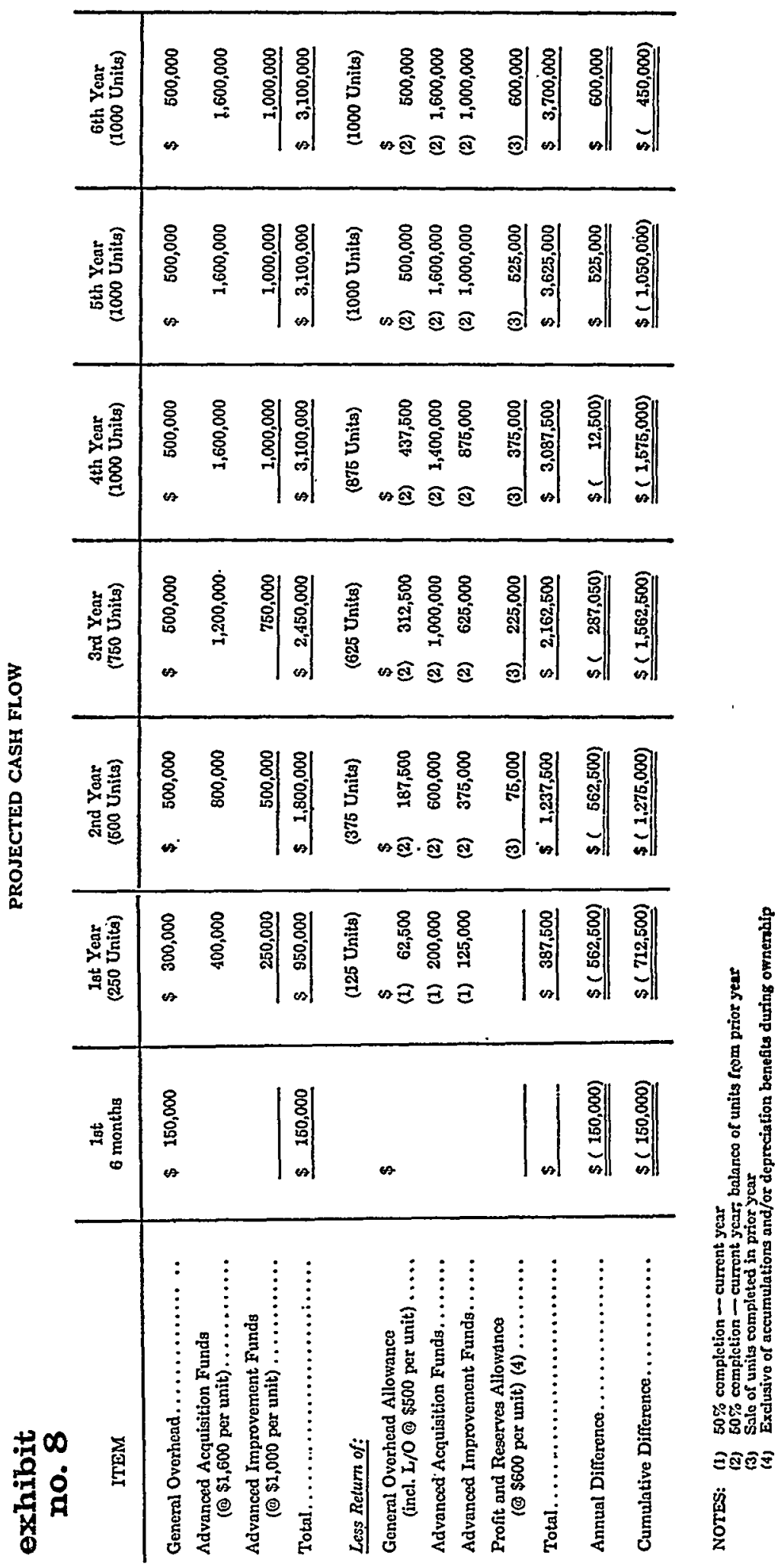

